Article

\title{
Antioxidant Effects of the Ethanol Extract from Flower of Camellia japonica via Scavenging of Reactive Oxygen Species and Induction of Antioxidant Enzymes
}

\author{
Mei Jing Piao ${ }^{1}$, Eun Sook Yoo ${ }^{1}$, Young Sang Koh ${ }^{1}$, Hee Kyoung Kang ${ }^{1}$, Junoh Kim ${ }^{2}$, \\ Yong Jin Kim ${ }^{2}$, Hak Hee Kang ${ }^{2}$ and Jin Won Hyun ${ }^{1}$ *
}

1 School of Medicine and Applied Radiological Science Research Institute, Jeju National University, Jeju 690-756, Korea; E-Mails: mjpiao@hanmail.net (M.J.P.); eunsyoo@jejunu.ac.kr (E.S.Y.); yskoh7@jejunu.ac.kr (Y.S.K.); pharmkhk@jejunu.ac.kr (H.K.K.)

2 Amore Pacific Co. R\&D Center, Yongin-si, Gyeonggi-do 446-729, Korea; E-Mails: junoh@amorepacific.com (J.K.); jaykim@amorepacific.com (Y.J.K.); hhkang@amorepacific.com (H.H.K.)

* Author to whom correspondence should be addressed; E-Mail: jinwonh@jejunu.ac.kr; Tel.: +82-64-754-3838; Fax: +82-64-702-2687.

Received: 24 March 2011; in revised form: 11 April 2011 / Accepted: 12 April 2011 / Published: 18 April 2011

\begin{abstract}
The aim of this study was to investigate the antioxidant properties of the ethanol extract of the flower of Camellia japonica (Camellia extract). Camellia extract exhibited 1,1-diphenyl-2-picrylhydrazyl radical and intracellular reactive oxygen species (ROS) scavenging activity in human $\mathrm{HaCaT}$ keratinocytes. In addition, Camellia extract scavenged superoxide anion generated by xanthine/xanthine oxidase and hydroxyl radical generated by the Fenton reaction $\left(\mathrm{FeSO}_{4}+\mathrm{H}_{2} \mathrm{O}_{2}\right)$ in a cell-free system, which was detected by electron spin resonance spectrometry. Furthermore, Camellia extract increased the protein expressions and activity of cellular antioxidant enzymes, such as superoxide dismutase, catalase and glutathione peroxidase. These results suggest that Camellia extract exhibits antioxidant properties by scavenging ROS and enhancing antioxidant enzymes. Camellia extract contained quercetin, quercetin-3-O-glucoside, quercitrin and kaempferol, which are antioxidant compounds.
\end{abstract}

Keywords: antioxidant effect; Camellia japonica; reactive oxygen species 


\section{Introduction}

Oxidative damage initiated by reactive oxygen species (ROS) is a major contributor to the aging process [1]. Skin is a major candidate and target of oxidative stress, and during the skin aging process, ROS levels rise and antioxidant defenses decline [2]. Due to the high prevalence of potential biological targets for oxidative damage, skin is very susceptible to such reactions. For example, skin is rich in lipids, proteins, and DNA, all of which are extremely sensitive to the oxidation process [3]. The antioxidant system is an important defense mechanism against oxidative cell damage [4]. The antioxidant system is consisted of intrinsic enzymes, including superoxide dismutase (SOD), catalase (CAT), glutathione peroxidase (GPx), glutathione reductase, and extrinsic antioxidant nutrients, which serve to reduce free radicals to less toxic states [5]. Some studies suggest that age-related decrease in antioxidant enzyme activity is consistent with increased free radical damage that contributes to aging [6].

Camellia japonica is a broad-leaved evergreen woody species, widely distributed in Japan and Korea. The flowers and flower buds of Camellia japonica have been used for the treatment of bleeding and as an anti-inflammation in oriental traditional medicine [7]. Studies have been conducted on the constituents of Camellia japonica, including saponins in fruits [8] and seeds [9], flavonol glycosides in leaves [10], and triterpenes, flavonols and phenolic compounds in flowers [11,12]. However, the biological effects of $C$. japonica have been less frequently studied. In the present study, we focused on investigating the in vitro antioxidant effect of the ethanol extract from flower of Camellia extract in human keratinocytes.

\section{Results}

Camellia extract did not show the cytotoxicity to human HaCaT keratinocytes at $6.25 \mu \mathrm{g} / \mathrm{mL}$, $12.5 \mu \mathrm{g} / \mathrm{mL}, 25 \mu \mathrm{g} / \mathrm{mL}$, and $50 \mu \mathrm{g} / \mathrm{mL}$ (Figure 1A). Camellia extract scavenged DPPH radical, 28\% at $6.25 \mu \mathrm{g} / \mathrm{mL}, 49 \%$ at $12.5 \mu \mathrm{g} / \mathrm{mL}, 58 \%$ at $25 \mu \mathrm{g} / \mathrm{mL}$, and $60 \%$ at $50 \mu \mathrm{g} / \mathrm{mL}$ compared to $89 \%$ at $2 \mathrm{mM}$ of NAC used as positive control (Figure 1B). Fluorescence spectrometric data revealed that intracellular ROS scavenging activity of Camellia extract was consistent with its DPPH radical scavenging activity, $31 \%$ at $6.25 \mu \mathrm{g} / \mathrm{mL}, 50 \%$ at $12.5 \mu \mathrm{g} / \mathrm{mL}, 53 \%$ at $25 \mu \mathrm{g} / \mathrm{mL}$, and $57 \%$ at $50 \mu \mathrm{g} / \mathrm{mL}$ compared to $70 \%$ at $2 \mathrm{mM}$ of NAC (Figure 1C). The fluorescence intensity of DCF-DA staining was also measured using confocal microscope. Analysis of confocal microscope showed that Camellia extract reduced the red fluorescence intensity upon $\mathrm{H}_{2} \mathrm{O}_{2}$ treatment, thus reflecting a reduction of ROS generation (Figure 1D).

We chose $50 \mu \mathrm{g} / \mathrm{mL}$ as the optimal dose of Camellia extract for further investigations. Control or Camellia extract at $50 \mu \mathrm{g} / \mathrm{mL}$ showed no specific signal of superoxide anion, while in the xanthine/xanthine oxidase system, superoxide anion signal increased to 3239. Camellia extract treatment decreased superoxide anion signal in the xanthine/xanthine oxidase system to 1875 (Figure $2 \mathrm{~A}$ and $\mathrm{B}$ ). 
Figure 1. The effects of Camellia extract on cytotoxicity, scavenging DPPH radicals and intracellular ROS. (A) Cells were treated with various concentrations of Camellia extract. Cell viability was determined $24 \mathrm{~h}$ later by MTT assay. The data represent three experiments and are expressed as mean $\pm \mathrm{SE}$; (B) The amount of DPPH radical was determined spectrophotometrically at $520 \mathrm{~nm}$; (C) Intracellular ROS generated was detected using a spectrofluorometer after DCF-DA staining; (D) Representative confocal images illustrate the increase of red fluorescence intensity of DCF produced by ROS in $\mathrm{H}_{2} \mathrm{O}_{2}$ treated cells compared to control. * Indicates significantly different from control $(p<0.05)$.

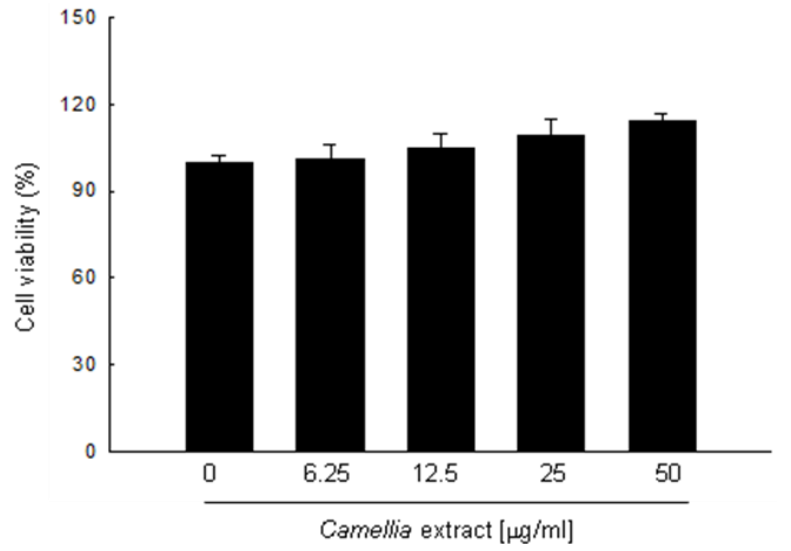

(A)

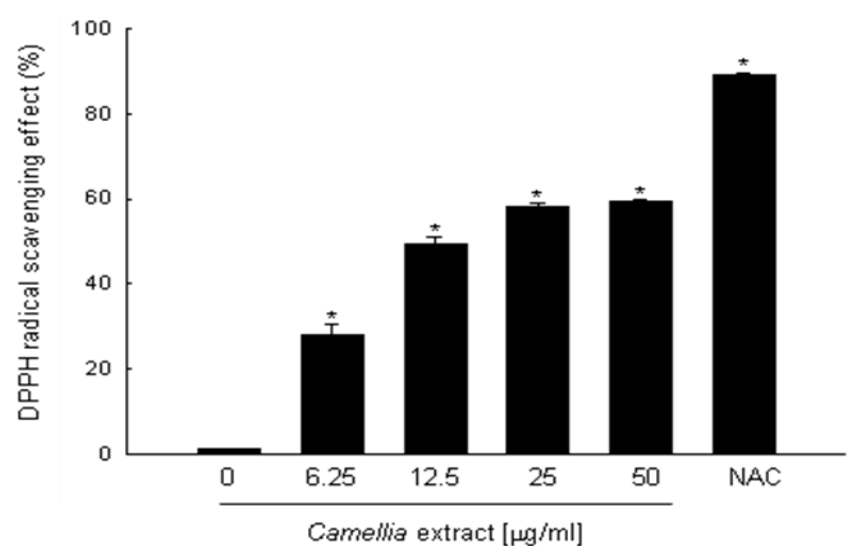

(B)

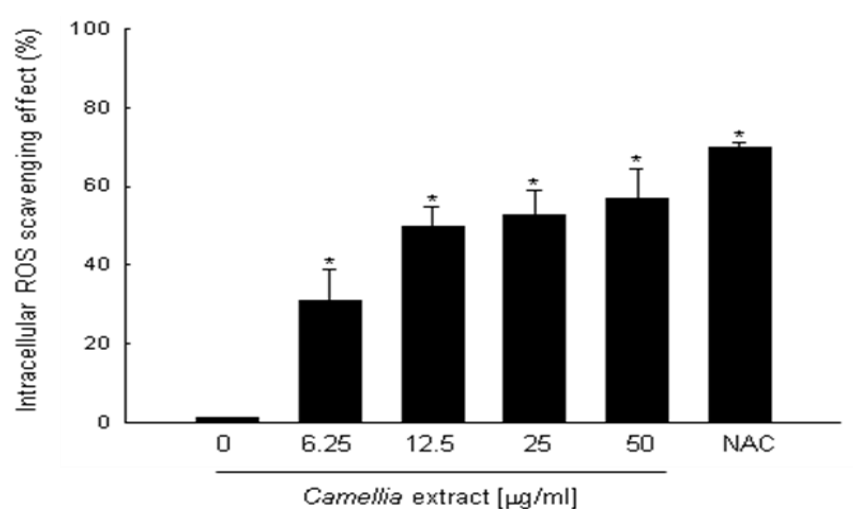

(C)

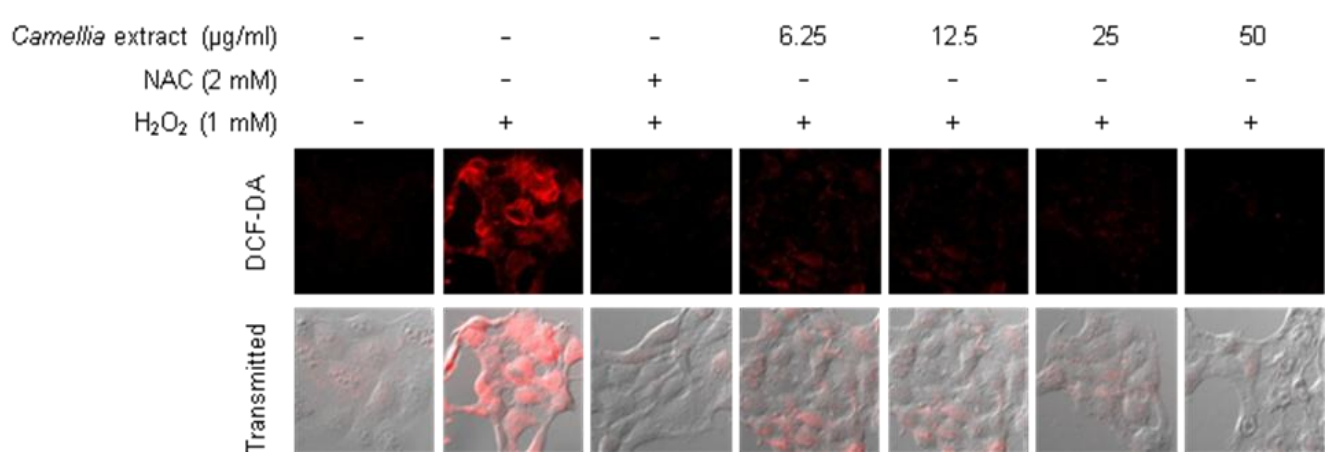

(D) 
Figure 2. The scavenging effect of Camellia extract against superoxide anion. Superoxide anion generated by xanthine and xanthine oxidase reacted with DMPO, and the resultant DMPO/OOH adducts were detected by ESR spectrometry. Results are shown in (A) histogram (mean $\pm \mathrm{SE}$ ) and (B) representative peak data. * Indicates significantly different from control $(p<0.05)$.

A

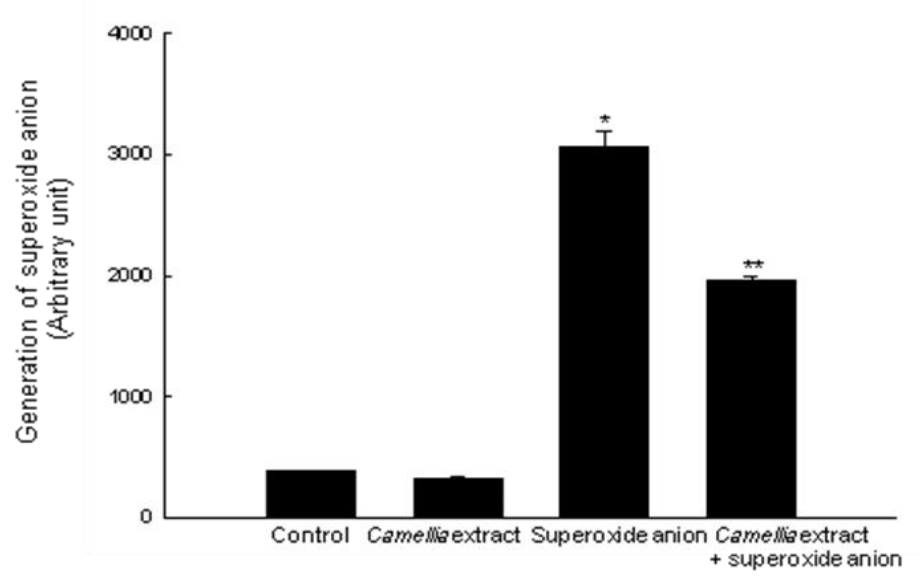

B

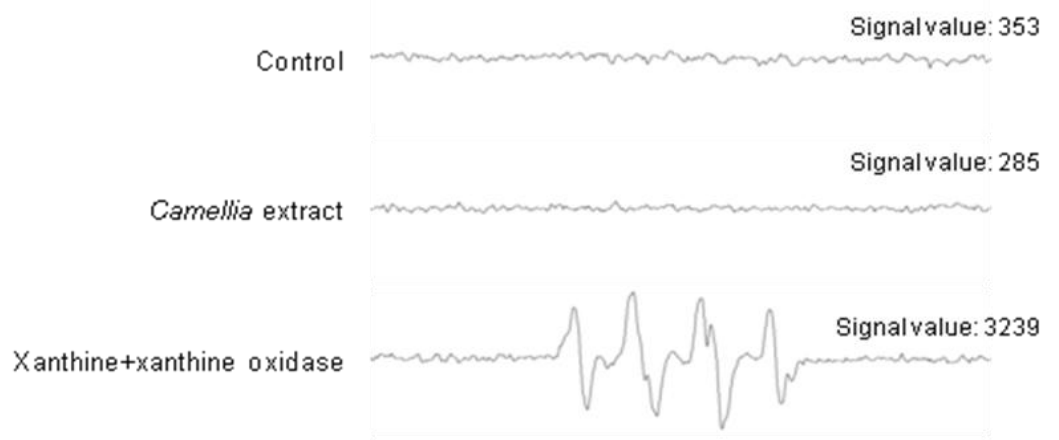

Xanthine+xanthine oxidase + Camellia extract

Signalvalue: 1875

Similarly, Camellia extract decreased generation of hydroxyl radical in the $\mathrm{FeSO}_{4}+\mathrm{H}_{2} \mathrm{O}_{2}$ system from 3921 to 1533 (Figures 3A and B). Taken together, these results suggest that Camellia extract can directly scavenge ROS.

In order to investigate whether the radical scavenging activity of Camellia extract was mediated by antioxidant enzyme activities, the protein expressions and activities of SOD, CAT and GPx in Camellia extract-treated cells were measured. As shown in Figure 4A, Camellia extract increased the protein expressions of these antioxidant enzymes in a time-dependent manner. At $24 \mathrm{~h}$, the SOD activity with Camellia extract demonstrated $22.9 \mathrm{U} / \mathrm{mg}$ of protein, compared to $14.3 \mathrm{U} / \mathrm{mg}$ of protein in the control (Figure 4B, left). With respect to CAT, Camellia extract increased $23.4 \mathrm{U} / \mathrm{mg}$ of protein at $24 \mathrm{~h}$, compared to $15.0 \mathrm{U} / \mathrm{mg}$ of protein in the control (Figure 4B, middle). Finally, GPx activity in Camellia extract-treated cells was also significantly increased to $9.4 \mathrm{U} / \mathrm{mg}$ of protein at $24 \mathrm{~h}$, compared to $5.6 \mathrm{U} / \mathrm{mg}$ of protein in the control (Figure $4 \mathrm{~B}$, right). These results suggest that Camellia extract can increase the protein expressions and activities of antioxidant enzymes, such as SOD, CAT and GPx. 
Figure 3. The scavenging effect of Camellia extract against hydroxyl radical. Hydroxyl radical generated by the Fenton reaction $\left(\mathrm{H}_{2} \mathrm{O}_{2}+\mathrm{FeSO}_{4}\right)$ reacted with DMPO, and the resultant DMPO/OH adducts were detected by ESR spectrometry. Results are expressed in (A) histogram (mean $\pm \mathrm{SE}$ ), and (B) representative peak data. * Indicates significantly different from control $(p<0.05)$.

A

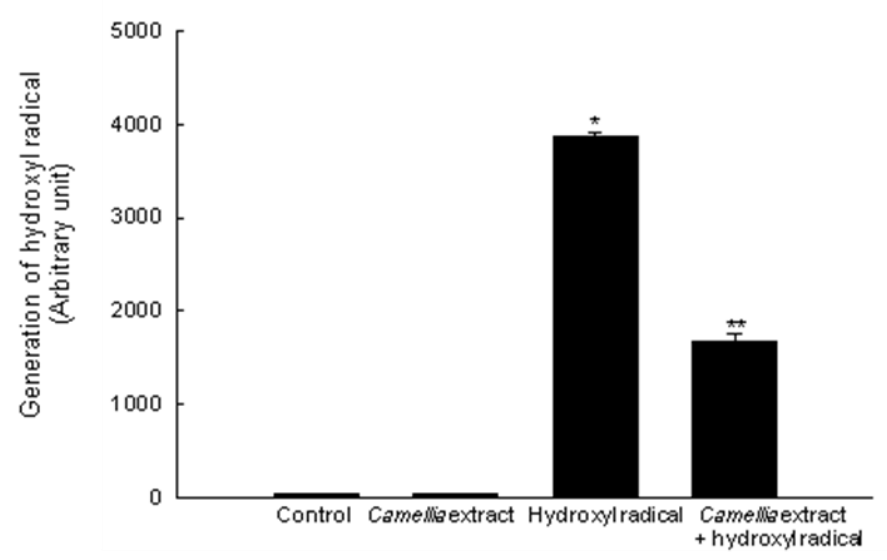

B

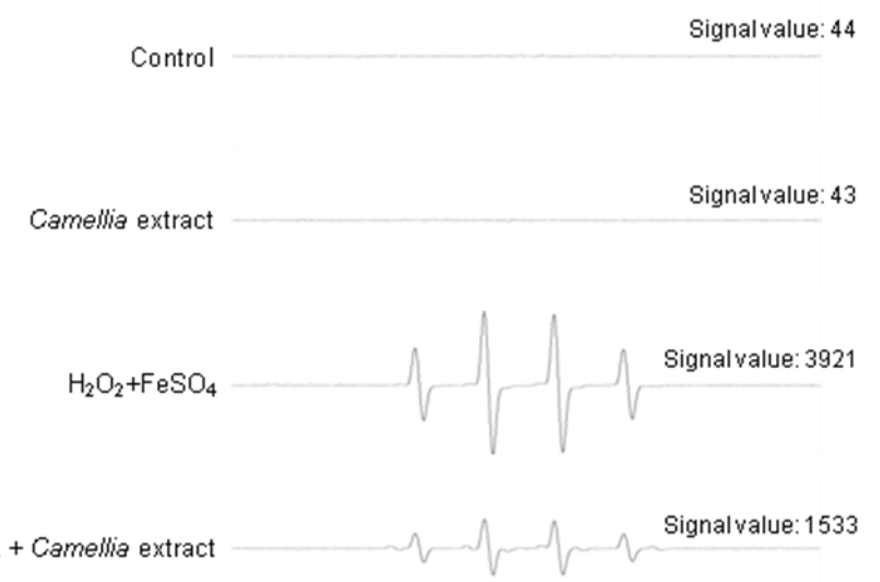

$\mathrm{H}_{2} \mathrm{O}_{2}+\mathrm{FeSO}_{4}+$ Camellia extract 
Figure 4. The effects of Camellia extract on protein expression and antioxidant enzyme activity. (A) SOD, (B) CAT and (C) GPx activity is expressed as unit per mg protein. * Indicates significantly different from control $(p<0.05)$.

A

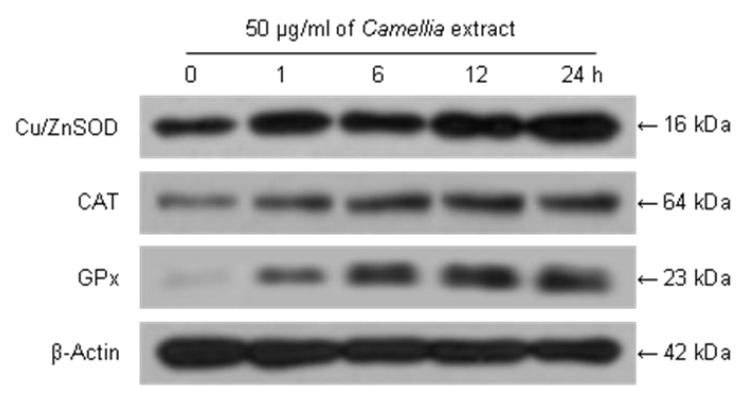

B

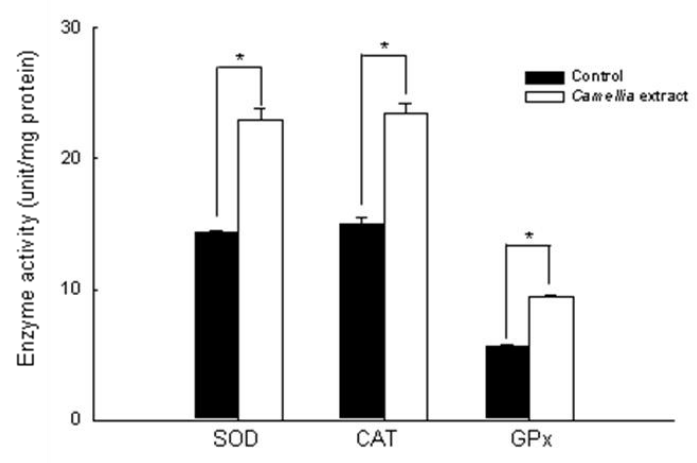

And LC-MS/MS chromatogram of Camellia extract showed quercetin, quercetin-3-O-glucoside, quercitrin (a glycoside rhamnose of quercetin) and kaempferol, which are antioxidant compounds (Figure 5).

Figure 5. LC-MS/MS chromatogram of flavonoids from Camellia extract. Each peak indicates (A) quercetin-3-O-glucoside, (B) quercitrin, (C) quercetin, and (D) kaempferol.

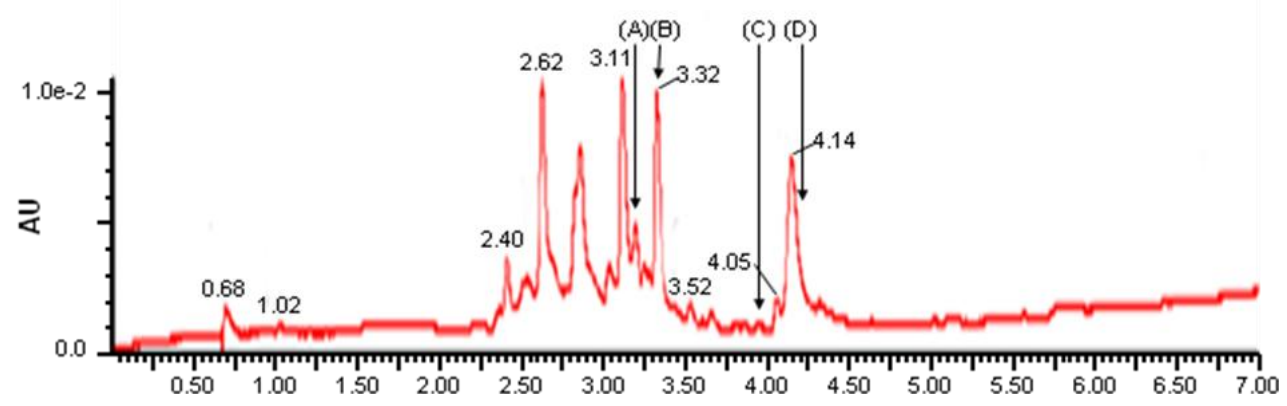

\section{Discussion}

The antioxidant properties of Camellia extract were evaluated in two categories: direct action on superoxide and hydroxyl radical scavenging in a cell-free system, and indirect action through induction of antioxidant enzymes. Camellia extract exerted direct scavenging activity on superoxide and hydroxyl radical as shown by ESR spectrometry. It was reported that the flower of $C$. japonica 
contained flavonols, such as quercetin, kaempferol, and sexangularetin, and phenolic compounds, such as $p$-hydroxybenzoic acid, protocatechuic acid and gallic acid [12]. The antioxidant compounds of Camellia extract in our study contained quercetin, quercetin-3-O-glucoside, quercitrin (a glycoside rhamnose of quercetin) and kaempferol. Quercetin exerts its antioxidant activity through scavenging ROS and preventing ROS formation with chelating transition metal ions, such as iron and copper [13,14]. Quercitrin has a free radical scavenging activity in a model of auto-oxidation of rat cerebral membranes [15]. Kaempferol has shown strong inhibitory/scavenging activity on ROS generation with numerous hydroxyl groups on their structures [16]. Moreover, it has been found to be a particularly potent blocker of extracellular ROS production, and to inhibit the ascorbate-dependent NADH oxidase and superoxide anion production activities of the neuronal plasma membrane redox chain [17]. Therefore, the ROS scavenging effect of Camellia extract demonstrated in this study might have been associated with flavonol or phenolic compounds.

Antioxidant enzymes, such as SOD, CAT, and GPx are the main antioxidant defense system. SOD plays an important role in scavenging superoxide anion which are formed during the early stages of oxidative stress, and in preventing aging [18]. SOD catalyzes the conversion of superoxide to hydrogen peroxide plus dioxygen. SOD can be classified into three groups, Cu/Zn SOD, Mn SOD, and Fe SOD, by the metals that they contain at their active sites. $\mathrm{Cu} / \mathrm{Zn}$ SOD is usually found in the cytoplasm of eukaryotic cells and Mn SOD in mitochondria, whereas prokaryotic cells contain Fe SOD and Mn SOD [19]. Hydrogen peroxide is a harmful by-product of many normal metabolic processes. However, CAT and GPx are frequently used by cells to rapidly catalyze the decomposition of hydrogen peroxide [20]. CAT catalyzes the formation of water and oxygen from hydrogen peroxide and prevents oxidative damage [21]. GPx is a well-known selenoenzyme that functions as an antioxidant, and catalyzes the reduction of hydroperoxides, including hydrogen peroxides, by reduced glutathione and protect cells from oxidative damage [22].

Quercetin has been reported to reduce or prevent oxidative stresses induced by ultraviolet A through activation of antioxidant enzymes and induction of their expressions [23]. Also, quercetin has antioxidant and cytoprotective properties against renal ischemia-reperfusion injury by inducing SOD, CAT, GPx expression and activating their activities [24]. Kaempferol enhances the antioxidant properties by raised antioxidant proteins expression, such as metallothionein, CAT, and SOD [25]. Moreover, kaempferol inhibits $\mathrm{H}_{2} \mathrm{O}_{2}$-induced lipid peroxidation and enhances the activity of SOD and CAT [26,27]. Quercitrin enhances intracellular antioxidant defense against free radicals by increasing production of antioxidant enzymes [28]. Camellia extract increased the activity and protein levels of these enzymes, which may mediate its inhibition of ROS production. Thus, Camellia extract not only directly quenches ROS, but also indirectly induces antioxidant enzymes. In conclusion, Camellia extract exerts in vitro its antioxidant properties by scavenging ROS and enhancing antioxidant enzymes activities (Figure 6). 
Figure 6. A proposed antioxidant action of Camellia extract, which explains scavenging of ROS and the enhancing effect of antioxidant enzymes.

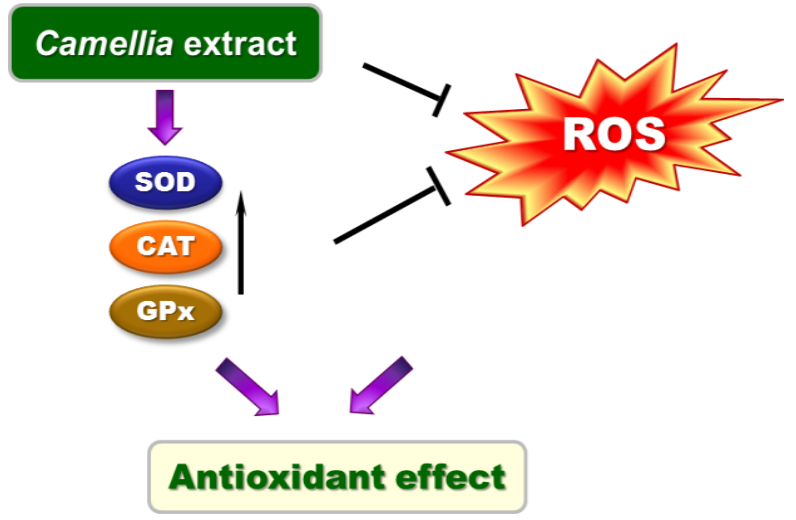

\section{Experimental Section}

\subsection{Reagents}

Camellia extract was obtained from the Amore Pacific Company (Gyeonggi-do, Korea). The UPLC-MS profile of Camellia extract was obtained from Jeju bio-industry development center of Jejutechnopark (Jeju, Korea). 1,1-Diphenyl-2-picrylhydrazyl (DPPH) radical, $N$-acetyl cysteine (NAC), 5,5-dimethyl-1-pyrroline- $N$-oxide (DMPO) and 2',7'-dichlorodihydrofluorescein diacetate (DCF-DA) were purchased from the Sigma chemical company (St. Louis, MO, USA). Cu/Zn SOD and CAT antibodies were purchased from the Biodesign international company (Saco, Maine, USA). GPx antibody was purchased from Santa Cruz biotechnology (Delaware Avenue, CA, USA). All other chemicals and reagents used were of analytical grade.

\subsection{Cell Culture}

The HaCaT (human keratinocyte) cells were maintained at $37{ }^{\circ} \mathrm{C}$ in an incubator, at a humidified atmosphere of 5\% $\mathrm{CO}_{2}$, and cultured in Dulbecco's modified Eagle's medium containing 10\% heat-inactivated fetal calf serum, streptomycin $(100 \mu \mathrm{g} / \mathrm{mL})$ and penicillin $(100 \mathrm{U} / \mathrm{mL})$.

\subsection{Cell Viability Assay}

Cells were seeded in a 96 well plate at a concentration of $1 \times 10^{5}$ cells $/ \mathrm{mL}$, and after plating for $16 \mathrm{~h}$, Camellia extract at $6.25,12.5,25$, and $50 \mu \mathrm{g} / \mathrm{mL}$ was added to the plate. After incubating for $24 \mathrm{~h}$ at $37{ }^{\circ} \mathrm{C}$, fifty microliter of MTT stock solution $(2 \mathrm{mg} / \mathrm{mL})$ was added to each well of a total reaction volume of $200 \mu \mathrm{L}$. After incubating for $4 \mathrm{~h}$, the plate was centrifuged at $800 \times \mathrm{g}$ for $5 \mathrm{~min}$ and the supernatants aspirated. The formazan crystals in each well were dissolved in $150 \mu \mathrm{L}$ dimethylsulfoxide and the absorbance at $540 \mathrm{~nm}$ read on a scanning multi-well spectrophotometer. 


\subsection{DPPH Radical Scavenging Activity}

Camellia extract at $6.25,12.5,25$, and $50 \mu \mathrm{g} / \mathrm{mL}(10 \mu \mathrm{L})$ were added to a $1 \times 10^{-4} \mathrm{M}$ solution of DPPH $(190 \mu \mathrm{L})$ in methanol. The resulting reaction mixture was shaken vigorously. After $3 \mathrm{~h}$, the amount of remaining DPPH was determined at $520 \mathrm{~nm}$ using a spectrophotometer.

\subsection{Intracellular ROS Scavenging Activity}

The DCF-DA method was used to detect the intracellular ROS levels [29]. Cells were seeded $1.5 \times 10^{5}$ cells/well and $16 \mathrm{~h}$ after plating, cells were treated with Camellia extract at 6.25, 12.5, 25, and $50 \mu \mathrm{g} / \mathrm{mL}(10 \mu \mathrm{L})$. After $30 \mathrm{~min}, 1 \mathrm{mM}$ of $\mathrm{H}_{2} \mathrm{O}_{2}(10 \mu \mathrm{L})$ was added to the plate. Cells were incubated for an additional $30 \mathrm{~min}$ at $37{ }^{\circ} \mathrm{C}$. After the addition of $25 \mu \mathrm{M}$ of DCF-DA solution for 10 min, fluorescence of 2',7'-dichlorofluorescein was detected using a PerkinElmer LS-5B spectrofluorometer. Image analysis for the generation of intracellular ROS was achieved by seeding cells on a cover-slip loaded six well plate at $2 \times 10^{5}$ cells/well. Sixteen hours after plating, cells were treated with Camellia extract. One hour later, $1 \mathrm{mM}$ of $\mathrm{H}_{2} \mathrm{O}_{2}$ was added to the plate. Twenty four hours later, $100 \mu \mathrm{M}$ DCF-DA was added to each well and the cells were incubated for an additional $30 \mathrm{~min}$ at $37{ }^{\circ} \mathrm{C}$. After washing with phosphate buffered saline (PBS), the stained cells were mounted onto a microscope slide in mounting medium (DAKO, Carpinteria, CA, USA). Images were collected using the laser scanning microscope 5 PASCAL program (Carl Zeiss, Jena, Germany) on a confocal microscope.

\subsection{Detection of Superoxide Anion}

Superoxide anion was generated by xanthine and xanthine oxidase, which were then quickly reacted with a nitrone spin trap, DMPO. The resultant DMPO/.OOH adducts were detected using an electron spin resonance (ESR) spectrometer. The ESR spectrum was recorded using JES-FA ESR spectrometer (JEOL, Tokyo, Japan), at 2.5 min after being mixed in a phosphate buffer solution (pH 7.4) with $20 \mu \mathrm{L}$ of $3 \mathrm{M}$ DMPO, $20 \mu \mathrm{L}$ of $10 \mathrm{mM}$ xanthine, $20 \mu \mathrm{L}$ of $0.25 \mathrm{U}$ xanthine oxidase, and $50 \mu \mathrm{g} / \mathrm{mL}$ of Camellia extract. The parameters of the ESR spectrometer were set at the following conditions: magnetic field of $336.5 \mathrm{mT}$, power of $5.00 \mathrm{~mW}$, frequency of $9.4380 \mathrm{GHz}$, modulation amplitude of $0.2 \mathrm{mT}$, gain of 200 , scan time of $0.5 \mathrm{~min}$, scan width of $10 \mathrm{mT}$, time constant of $0.03 \mathrm{sec}$, and a temperature of $25^{\circ} \mathrm{C}$.

\subsection{Detection of Hydroxyl Radical}

Hydroxyl radicals were generated by the Fenton reaction $\left(\mathrm{H}_{2} \mathrm{O}_{2}+\mathrm{FeSO}_{4}\right)$, which were then quickly reacted with DMPO. The resultant DMPO/OH adducts were detected using an ESR spectrometer. The ESR spectrum was recorded using JES-FA ESR spectrometer at $2.5 \mathrm{~min}$ after being mixed in a phosphate buffer solution (pH 7.4) with $0.2 \mathrm{ml}$ of $0.3 \mathrm{M}$ DMPO, $0.2 \mathrm{~mL}$ of $10 \mathrm{mM} \mathrm{FeSO}_{4}, 0.2 \mathrm{~mL}$ of $10 \mathrm{mM} \mathrm{H}_{2} \mathrm{O}_{2}$, and $50 \mu \mathrm{g} / \mathrm{mL}$ of Camellia extract. The parameters of the ESR spectrometer were set at the following conditions: magnetic field of $336.5 \mathrm{mT}$, power of $1.00 \mathrm{~mW}$, frequency of $9.4380 \mathrm{GHz}$, modulation amplitude of $0.2 \mathrm{mT}$, gain of 200 , scan time of $0.5 \mathrm{~min}$, scan width of $10 \mathrm{mT}$, time constant of $0.03 \mathrm{sec}$, and a temperature of $25^{\circ} \mathrm{C}[30]$. 


\subsection{Western Blot Analysis}

Cells were lysed in $100 \mu \mathrm{L}$ of a lysis buffer [120 mM NaCl, $40 \mathrm{mM}$ Tris (pH 8), 0.1\% NP 40]. Aliquots of the lysates (40 $\mu \mathrm{g}$ of protein) were boiled for $5 \mathrm{~min}$ and electrophoresed in $10 \%$ SDS-polyacrylamide gel. The blots in the gels were transferred onto nitrocellulose membranes (Bio-Rad, Hercules, CA, USA), and subsequently incubated with anti-primary antibodies. The membranes were further incubated with secondary anti-immunoglobulin-G-horseradish peroxidase conjugates (Pierce, Rockford, IL, USA), followed by exposure to X-ray film. The protein bands were detected using an enhanced chemiluminescence western blotting detection kit (Amersham, Little Chalfont, Buckinghamshire, UK).

\subsection{Measurement of SOD Activity}

Cells were seeded in a culture dish at $1 \times 10^{5}$ cells $/ \mathrm{mL}$, and were treated with Camellia extract at $50 \mu \mathrm{g} / \mathrm{mL}$. After $1 \mathrm{~h}, 150 \mu \mathrm{M}$ of $\mathrm{H}_{2} \mathrm{O}_{2}$ was added to the plate, which was incubated for a further $24 \mathrm{~h}$. The harvested cells were suspended in $10 \mathrm{mM}$ phosphate buffer ( $\mathrm{pH}$ 7.5) and then lysed on ice by sonicating twice for $15 \mathrm{sec}$. Triton X-100 (1\%) was then added to the lysates and was incubated for $10 \mathrm{~min}$ on ice. The lysates were centrifuged at $5,000 \times \mathrm{g}$ for $10 \mathrm{~min}$ at $4{ }^{\circ} \mathrm{C}$ to remove the cellular debris. Fifty micrograms of protein was added to $500 \mathrm{mM}$ phosphate buffer ( $\mathrm{pH}$ 10.2) and $1 \mathrm{mM}$ epinephrine. Epinephrine rapidly undergoes auto-oxidation at $\mathrm{pH} 10$ to produce adrenochrome, a pink-colored product, which was assayed at $480 \mathrm{~nm}$ using an ultraviolet/visible spectrophotometer in kinetic mode. SOD inhibits auto-oxidation of epinephrine. The rate of inhibition was monitored at $480 \mathrm{~nm}$ and the amount of enzyme required to produce $50 \%$ inhibition was expressed as units/mg protein.

\subsection{Measurement of CAT Activity}

Fifty milligrams of protein was added to $50 \mathrm{mM}$ phosphate buffer ( $\mathrm{pH}$ 7) containing $100 \mathrm{mM} \mathrm{H}_{2} \mathrm{O}_{2}$. The reaction mixture was incubated for $2 \mathrm{~min}$ at $37{ }^{\circ} \mathrm{C}$ and the absorbance was monitored at $240 \mathrm{~nm}$ for $5 \mathrm{~min}$. The change in absorbance with time was proportional to the breakdown of $\mathrm{H}_{2} \mathrm{O}_{2}$. The amount of enzyme required to breakdown $1 \mathrm{mM}$ of $\mathrm{H}_{2} \mathrm{O}_{2}$ was expressed as units/mg protein.

\subsection{Measurement of GPx Activity}

Fifty milligrams of protein was added to $25 \mathrm{mM}$ of phosphate buffer $(\mathrm{pH} 7.5)$ containing $1 \mathrm{mM}$ EDTA, $1 \mathrm{mM} \mathrm{NaN}_{3}, 1 \mathrm{mM}$ glutathione, 0.25 units of glutathione reductase and $0.1 \mathrm{mM} \mathrm{NADPH}$. After incubation for $10 \mathrm{~min}$ at $37^{\circ} \mathrm{C}, \mathrm{H}_{2} \mathrm{O}_{2}$ was added to the reaction mixture at a final concentration of $1 \mathrm{mM}$. Absorbance was monitored at $340 \mathrm{~nm}$ for $5 \mathrm{~min}$. GPx activity was measured as the rate of NADPH oxidation by change in absorbance at $340 \mathrm{~nm}$. The amount of enzyme required to oxidize $1 \mathrm{mM}$ NADPH was expressed as units/mg protein. 


\subsection{Statistical Analysis}

All the measurements were made in triplicate and all values are represented as means \pm standard error (SE). The results were subjected to an analysis of the variance (ANOVA) using the Tukey test to analyze the difference. The $\mathrm{p}<0.05$ was considered significant.

\section{Acknowledgements}

This study was financially supported by the Leading Industry Development Projects for the Economic Region funded by the Ministry of Knowledge Economy (MKE) (Water Industry Project for Jeju).

\section{References}

1. Ross, C.; Alston, M.; Bickenbach, J.R.; Aykin-Burns, N. Oxygen tension changes the rate of migration of human skin keratinocytes in an age-related manner. Exp. Dermatol. 2011, 20, 58-63.

2. Laskin, J.D.; Black, A.T.; Jan, Y.H.; Sinko, P.J.; Heindel, N.D.; Sunil, V.; Heck, D.E.; Laskin, D.L. Oxidants and antioxidants in sulfur mustard-induced injury. Ann. NY Acad. Sci. 2010, 1203, 92-100.

3. Vileno, B.; Jeney, S.; Sienkiewicz, A.; Marcoux, P.R.; Miller, L.M.; Forró, L. Evidence of lipid peroxidation and protein phosphorylation in cells upon oxidative stress photo-generated by fullerols. Biophys. Chem. 2010, 152, 164-169.

4. Dreger, H.; Westphal, K.; Weller, A.; Baumann, G.; Stangl, V.; Meiners, S.; Stangl, K. Nrf2-dependent upregulation of antioxidative enzymes: A novel pathway for proteasome inhibitor-mediated cardioprotection. Cardiovasc. Res. 2009, 83, 354-361.

5. Vertuani, S.; Angusti, A.; Manfredini, S. The antioxidants and pro-antioxidants network: An overview. Curr. Pharm. Des. 2004, 10, 1677-1694.

6. Habdous, M.; Herbeth, B.; Vincent-Viry, M.; Lamont, J.V.; Fitzgerald, P.S.; Visvikis, S.; Siest, G. Serum total antioxidant status, erythrocyte superoxide dismutase and whole-blood glutathione peroxidase activities in the Stanislas cohort: Influencing factors and reference intervals. Clin. Chem. Lab. Med. 2003, 41, 209-215.

7. Yoshikawa, M.; Morikawa, T.; Asao, Y.; Fujiwara, E.; Nakamura, S.; Matsuda, H. Medicinal flowers. XV. The structures of noroleanane- and oleanane-type triterpene oligoglycosides with gastroprotective and platelet aggregation activities from flower buds of Camellia japonica L. Chem. Pharm. Bull. 2007, 55, 606-612.

8. Itokawa, H.; Sawada, N.; Murakami, T. Structures of camelliagenins A, B, and C obtained from Camellia japonica. Chem. Pharm. Bull. 1969, 17, 474-480.

9. Yoshikawa, M.; Harada, E.; Murakami, T.; Matsuda, H.; Yamahara, J.; Murakami, N. Camelliasaponins B1, B2, C1 and C2, new type inhibitors of ethanol absorption in rats from the seeds of Camellia japonica L. Chem. Pharm. Bull. 1994, 42, 742-744.

10. Onodera, K.; Hanashiro, K.; Yasumoto, T. Camellianoside, a novel antioxidant glycoside from the leaves of Camellia japonica. Biosci. Biotech. Biochem. 2006, 70, 1995-1998.

11. Itokawa, H.; Nakajima, H.; Ikuta, A.; Iitaka, Y. Two triterpenes from the flowers of Camellia japonica. Phytochemistry 1981, 20, 2539-2542. 
12. Nakajima, H.; Itokawa, H.; Ikuta, A. Studies on the constituents of the flower of Camellia japonica (2). Yakugaku Zasshi 1984, 104, 157-161 (in Japanese).

13. Afanasev, I.B.; Dorozhko, A.I.; Brodskii, A.V.; Kostyuk, V.A.; Potapovitch, A.I. Chelating and free radical scavenging mechanisms of inhibitory action of rutin and quercetin in lipid peroxidation. Biochem. Pharmacol. 1989, 38, 1763-1769.

14. Van Acker, S.A.; van Balen, G.P.; van den Berg, D.J.; Bast, A.; van der Vijgh, W.J. Influence of iron chelation on the antioxidant activity of flavonoids. Biochem. Pharmacol. 1998, 56, 935-943.

15. Saija, A.; Scalese, M.; Lanza, M.; Marzullo, D.; Bonina, F.; Castelli, F. Flavonoids as antioxidant agents: Importance of their interaction with biomembranes. Free Radic. Biol. Med. 1995, 19, 481-486.

16. Jung, H.A.; Jung, M.J.; Kim, J.Y.; Chung, H.Y.; Choi, J.S. Inhibitory activity of flavonoids from Prunus davidiana and other flavonoids on total ROS and hydroxyl radical generation. Arch. Pharm. Res. 2003, 26, 809-815.

17. Samhan-Arias, A.K.; Martín-Romero, F.J.; Gutiérrez-Merino, C. Kaempferol blocks oxidative stress in cerebellar granule cells and reveals a key role for reactive oxygen species production at the plasma membrane in the commitment to apoptosis. Free Radic. Biol. Med. 2004, 37, 48-61.

18. Emerit, I.; Filipe, P.; Freitas, J.; Vassy, J. Protective effect of superoxide dismutase against hair graying in a mouse model. Photochem. Photobiol. 2004, 80, 579-582.

19. Alscher, R.G.; Erturk, N.; Heath, L.S. Role of superoxide dismutases (SODs) in controlling oxidative stress in plants. J. Exp. Bot. 2002, 53, 1331-1341.

20. Bose Girigoswami, K.; Bhaumik, G.; Ghosh, R. Induced resistance in cells exposed to repeated low doses of $\mathrm{H}_{2} \mathrm{O}_{2}$ involves enhanced activity of antioxidant enzymes. Cell Biol. Int. 2005, 29, 761-767.

21. Rajeshkumar, N.V.; Ramadasan, K. Modulation of carcinogenic response and antioxidant enzymes of rats administered with 1, 2-dimethyl hydrazine by Picroliv. Cancer Lett. 2003, 191, 137-143.

22. Thu, V.T.; Kim, H.K.; Ha, S.H.; Yoo, J.Y.; Park, W.S.; Kim, N.; Oh, G.T.; Han, J. Glutathione peroxidase 1 protects mitochondria against hypoxia/reoxygenation damage in mouse hearts. Pflugers. Arch. 2010, 460, 55-68.

23. Erden, I.M.; Kahraman, A. The protective effect of flavonol quercetin against ultraviolet a induced oxidative stress in rats. Toxicology 2000, 154, 21-29.

24. Inal, M.; Altinişik, M.; Bilgin, M.D. The effect of quercetin on renal ischemia and reperfusion injury in the rat. Cell. Biochem. Funct. 2002, 20, 291-296.

25. Kameoka, S.; Leavitt, P.; Chang, C.; Kuo, S.M. Expression of antioxidant proteins in human intestinal Caco-2 cells treated with dietary flavonoids. Cancer Lett. 1999, 146, 161-167.

26. Jung, C.H.; Jun, C.Y.; Lee, S.; Park, C.H.; Cho, K.; Ko, S.G. Rhus verniciflua stokes extract: Radical scavenging activities and protective effects on $\mathrm{H}_{2} \mathrm{O}_{2}$-induced cytotoxicity in macrophage RAW 264.7 cell lines. Biol. Pharm. Bull. 2006, 29, 1603-1607.

27. Söhretoğlu, D.; Sabuncuoğlu, S.A.; Sakar, M.K.; Ozgüneş, H.; Sterner, O. Antioxidant effects of secondary metabolites from Geranium psilostemon. Nat. Prod. Commun. 2010, 5, 899-902.

28. Kandaswami, C.; Middleton, E., Jr. Free radical scavenging and antioxidant activity of plant flavonoids. Adv. Exp. Med. Biol. 1994, 366, 351-376. 
29. Rosenkranz, A.R.; Schmaldienst, S.; Stuhlmeier, K.M.; Chen, W.; Knapp, W.; Zlabinger, G.J. A microplate assay for the detection of oxidative products using 2',7'-dichlorofluorescin-diacetate. J. Immunol. Method. 1992, 156, 39-45.

30. Rimbach, G.; Weinberg, P.D.; de Pascual-Teresa, S.; Alonso, M.G.; Ewins, B.A.; Turner, R.; Minihane, A.M.; Botting, N.; Fairley, B.; Matsugo, S.; Uchida, Y.; Cassidy, A. Sulfation of genistein alters its antioxidant properties and its effect on platelet aggregation and monocyte and endothelial function. Biochim. Biophys. Acta 2004, 1670, 229-237.

(C) 2011 by the authors; licensee MDPI, Basel, Switzerland. This article is an open access article distributed under the terms and conditions of the Creative Commons Attribution license (http://creativecommons.org/licenses/by/3.0/). 